\title{
The relationship between service quality and customer satisfaction in the South African mobile network telecommunications industry
}

\author{
Herring Shava \\ Department of Management, Walter Sisulu University, \\ South Africa \\ bshava@,wsu.ac.za \\ ORCID 0000-0002-2094-9585
}

Abstract. The mobile network telecommunications sector is rapidly growing in South Africa but research focusing on customer service and customer satisfaction lags behind. Customer satisfaction is critical for brand protection, market share growth and customer loyalty. Research is needed to identify the key aspects which contribute to customer satisfaction. The study investigates whether service quality dimensions (tangibility, reliability, responsiveness, empathy, and assurance), predict customer satisfaction after controlling for customer characteristics namely, sex, age, and education level. A sample of 1451 mobile network users was used. To collect primary data, self-administered questionnaires were used. Hierarchical regression analysis was performed and the results reveal that age and education level had no unique contribution but customers' sex had a statistically significant negative unique contribution to the model. Further, after controlling for sex, age and education level, service quality dimensions, that is, assurance, tangibility, reliability, and empathy had major unique contributions, while responsiveness had a unique minor contribution towards enhancing customer satisfaction experience. The findings are critical to market segmentation practices of mobile network operators as this research indicates that demographic factors play a significant role in ensuring that customer service efforts yield the intended results.

Keywords: service quality, customer satisfaction, mobile network operators, age, sex, education level.

JEL Classification: L86, M310 


\section{INTRODUCTION}

The ability to deliver superior service quality is critical to any firm's quest for profits, growth, and market share. Profitability growth and market share materialise in the presence of loyal customers who do not hesitate to pay a price premium when dealing with the firm, leading to a low cost of handling. The mentioned aspects only come true when customers are satisfied with the service quality they receive from the firm (Alabar et al., 2014; Mazibuko, 2016). As a result, delivering superior service quality leading to customer satisfaction is a priority goal of South African (SA) mobile network operators.

Figures published by the Independent Communications Authority South Africa (ICASA, 2019) reveal that the mobile network telecommunications industry has shown tremendous growth, with total revenue rising from R78 billion in 2015 to R99 billion in 2018. Despite this growth, industry writers indicate that South African customers in the mobile network telecommunications industry are dissatisfied with the service they receive from mobile network operators (Khumalo, 2019). However, it is not clear from literature as to the "what of" service quality predicts customer satisfaction in the South African mobile network telecommunications industry so as to come up with targeted strategies earmarked to enhance customer satisfaction experience in SA's mobile network telecommunications industry. This study therefore argues that investigating the relationship between service quality and customer satisfaction, especially the "what of" service quality, in relation to overall customer satisfaction is now more critical than ever in SA's mobile network telecommunications industry if this growth trajectory is to be maintained or surpassed.

Owing to customers having ease of access to information, they can easily arrive at a decision on who to buy from and who to avoid, without prior dealings with the service provider. By focusing on online customer postings, reviews and ratings on service providers, customers have enough information to conclude who they are likely to make a purchase from and this could dampen future growth prospects of the entire sector. Few empirical studies in South Africa have examined the link between service quality and customer satisfaction (see, Roberts-Lombard \& Petzer, 2018; Mpwanya, 2019).

Roberts-Lombard and Petzer (2018) did not focus on customer satisfaction per se but took a step further and focused on customer satisfaction/delight which in marketing literature is considered a higher order or an elevated level of customer satisfaction (see Berman, 2005; Fuller \& Matzler, 2008; Torres and Kline, 2013). As a result, customer satisfaction and customer satisfaction/delight are measured on a continuum where customer satisfaction is on the lower end while customer delight is on the upper end. By taking this approach, questions relating to the relationship between service quality and customer satisfaction experience in the SA mobile network telecommunications industry are not fully addressed.

This study differs from that of Roberts-Lombard and Petzer (2018) as it has focused on a wider aspect of service delivery that constitutes service quality, that is, tangibility, reliability, responsiveness, empathy and assurance as opposed to a narrow focus, that of perceived employee skills in service delivery. This study therefore subscribed to the SERVQUAL notion in measuring service quality as designed by Parasuraman et al. (1985). By focusing on this wider aspect, the study makes an assumption that service quality is a two-way effort, whereby both the service provider (the firm) and the employees make a combined or team effort to provide superior service delivery in a bid to satisfy customers. This study further differs in approach from that of Mpwanya (2019) who in measuring overall customer satisfaction made use of the Minnesota Customer Satisfaction Index with the score from 0 to 100. In this study a subdivided six item measured on a 7-point Likert scale is used as a tool to gather primary data relating to customer satisfaction. The research by Van der Wal, Pampallis and Bond (2002) used the SERVQUAL tool to measure customer service in the mobile network sector. They found that South African consumers perceived assurance, responsiveness and empathy as similar as these dimensions loaded as a single factor. 
Fifteen years later, Ngwenya (2017) used a similar tool and found that South African mobile network customers regarded assurance and responsiveness as the important predictors of customer satisfaction. Given mixed results in empirical studies, this study makes use of the SERVQUAL tool in an attempt to identify the predictors of customer satisfaction in South Africa's mobile network telecommunications sector. Mpwanya (2019) praised the exponential growth of the sector but lamented the death of South African literature focusing on customer satisfaction in this sector. Measurement of customer satisfaction should be a permanent and ongoing activity especially in the sectors that play a critical role in improving the living standards of citizens such as the mobile network telecommunications sector. The findings of such studies are critical for identifying expectations of customers, and managers can rely on such information to devise strategies that will enhance their market share. This study therefore seeks to answer the following question: Overall, does service quality experience as measured by tangibility, reliability, responsiveness, empathy, and assurance predict customer satisfaction in South Africa's mobile network telecommunications industry after controlling for customer characteristics (sex, age and education level)? This research is unique in the sense that it seeks to provide insights into the factors that are critical to marketers targeting the mobile network market. The paper is structured as follows: literature review, where the concepts of customer satisfaction and service quality are discussed at length and research hypotheses are formulated. Thereafter, the research methodology is discussed followed by results, discussion, limitations of the study, suggestions for further research and the study's conclusion.

\section{LITERATURE REVIEW}

\subsection{Customer satisfaction}

Across the globe, research in the telecommunications sector provides evidence reiterating the importance of customer satisfaction. For example, research in the United States of America has revealed that customer satisfaction is a strong predictor of customer loyalty (Lim et al., 2006). Supporting this finding are studies from Taiwan (Liu et al., 2011), and Nigeria (Adeleke \& Aminu, 2012). Customer satisfaction is critical to the entity because of the benefits that flow in its direction such as lower acquisition cost, base profit, revenue growth, cost savings, referrals and price premium (Lamb et al., 2015).

Acquisition costs are incurred by the firm in an attempt to recruit new customers by embarking on advertising, sales calls, public relations and promotions. Given that satisfied customers become loyal to the entity, chances are high that the mentioned costs may be the same per customer and the total acquisition costs may be dramatically very low for a firm with a large loyal customer base. Occasionally the firm will spend less in acquiring new customers to sustain its profitability.

Satisfied customers tend to stay longer with the service provider. More importantly, customers buy services at a price relatively higher than the cost incurred by the entity. The profit realised from such basic transactions, immune to time, loyalty, efficiency and other factors is base profit. Base profit increases significantly depending on the ability of the entity to keep the same customer satisfied and loyal to the entity.

Customer spending tends to increase over time in most businesses. The major contributor to this is that as customers wonder around the business from time-to-time, they take notice of other services or products offered by the retailer and begin buying these products as well. This practice leads to revenue growth for the retailer as spending by satisfied customers increases over time.

As customers become more accustomed to the business, they become more efficient. Customers who are more knowledgeable about their retailer do not waste time requesting for services and products 
that the retailer does not provide. In addition, they become less dependent on employees of the retailer for information and advice. Thus, productivity advantages that translate into lower cost are achieved through collaborative learning between the customer and the retailer given the passage of time.

Satisfied customers further recommend the entity to other potential customers, a behaviour termed word-of-mouth. According to Mazibuko (2016), positive word-of-mouth is a more credible source of information than advertising. Lamb et al. (2013) concurred and pointed out that positive-word-of-mouth is a critical source of advertising for any entity and many customers regard it as a more credible source of information than advertising.

Furthermore, when customers are satisfied, they often think that they are getting superior value. This is important to the entity and with time, they often react less to the entity's price adjustment, and are less likely to respond to the competitor's lower prices, specials and discounts. Interestingly, in many cases, so as to continue enjoying the superior value they are receiving from the entity, they are willing to pay a price premium.

\subsection{Service quality}

Researchers either investigate the influence of individual service quality dimensions on customer satisfaction or as a composite. This study ignored the composite approach and investigated the influence of each service quality dimension on customer satisfaction. According to Izogo (2017), delineating service quality dimensions allows researchers to have a clear picture of how they individually influence the dependent variable of interest, that is, customer satisfaction and this allows researchers to identify the dimension(s) to pay more attention to.

A long-standing debate on the link between service quality and customer satisfaction has led to the emergence of three schools of thought on this aspect. The first school of thought subscribes to the notion that satisfaction influences service quality. The second school of thought subscribes to the notion that service quality is an antecedent of satisfaction, while the third school of thought points out that the two can be synonymous (Kassim \& Abdullah, 2008). Literature investigating customer satisfaction and service quality in the mobile telecommunications sector seems to be favouring the second school of thought (Deng et al., 2010; Gao et al., 2015; Ofori et al., 2018). This research concurs with the literature investigating service quality and customer satisfaction in the mobile telecommunications sector which outlines that service quality is an antecedent of customer satisfaction. However, this study further contributes to the longstanding debate and provides evidence whether service quality is an antecedent of customer satisfaction. The service quality dimensions explored in this study are tangibility, reliability, responsiveness, empathy, and assurance. These are discussed at length in the paragraphs to follow.

\subsubsection{Tangibility}

According to Olatukun and Ojo (2016), tangibility revolves around the physical aspects of a service. Tangibility is all about visuals, that is, how the facilities, service personnel, tools and equipment which are utilised to deliver the service appear in the eyes of the consumer (Machado, 2014). In the case of a mobile network operator retail outlet, this could refer to the staff's appearance in terms of uniforms (if available) (Buttle \& Maklan, 2015). With respect to tangibility, the consumer asks several questions which include (1) staff members dressing - Are the staff members neatly dressed? (2) Cleanliness of staff members - Are the uniforms clean? etc.

With reference to equipment and tools of the mobile network operator, the customer would want to establish if the equipment and tools are relevant and in line with the technological advancements (Hudson 
\& Hudson, 2017). Sometimes customers are required to utilise the equipment found in house for certain transactions, for example computers and telephones/mobile phones. In such circumstances, the customer would rate the service provider's equipment focusing on user friendliness and general performance of the equipment.

The customer would also focus on weather regulation facilities, for example air conditioners or fans and their performance. The customer would also rate items like furniture such as the service desk, the chairs they sit on, among other pieces of furniture utilised for service delivery. Also, customers would rate the service provider on how the merchandise is arranged in the shop. Further, customers would focus on easiness to navigate in the vicinity and the time it takes for an individual to identify the desired item including the general cleanliness of the items on shelves, among other aspects.

Last, the customer would rate the facilities' exterior and interior (Zeithaml et al., 2013). For the exterior, they focus on the design of the structure, availability of parking, landscape, signage and general maintenance issues of the physical structure. Inside the structure, customers focus on cleanliness, adequate lighting, general design, layout, air temperature and signage in-store. Other tangibles include the mobile network operator's brochures, business cards, invoices, marketing material (posters and banners), reports, statements, stationery, and website (Hudson \& Hudson, 2017).

\subsubsection{Service reliability}

Parasuraman et al. (1988) defined service reliability as the entity's ability to render services to its customers when or as promised, leading to them being able to depend on it whenever the need arises. Recent literature has expanded on this concept by pointing out that service reliability also includes informing customers on promotions and prices timeously (Martinelli \& Balboni, 2012; Izogo, 2016).

\subsubsection{Service responsiveness}

Among other issues, customers value time and they generally do not like to be kept waiting for more than the average time before the service is delivered. Therefore, responsiveness refers to the ability of the service team to deliver prompt service. When the service is delayed beyond the average expected time (lead time), this creates a negative perception of service quality (Olatukun \& Ojo, 2016). As outlined earlier, the BrandsEye (2019) reported that South African consumers complain a lot regarding this aspect as mobile network operators were taking longer to respond to complaints posted on social media platforms and when they eventually responded, at least $60 \%$ of the consumers ended up displeased.

\subsubsection{Empathy}

Machado (2014) defined empathy as a sincere expression of feeling for the customer's circumstances. Basically, empathy is categorised as a service failure recovery strategy. On that note, the service team is encouraged to show empathy towards the customer who may be facing major or minor challenges. Olatokun and Ojo (2016) pointed out that service team approachability, its sense of security, and the ability to engage the customer in trying to solve their needs are examples of empathy.

\subsubsection{Service assurance}

By definition, service assurance refers to knowledge and the extent of professionalism practised by workers and their ability to make customers trust and have confidence in the firm's capabilities 
(Parasuraman et al., 1988). Izogo (2015) weighed in and pointed out that service assurance is critical as it can be used as a tool to remove uncertainties customers may have regarding the firm's ability to deliver.

\subsection{Service quality, customer characteristics and satisfaction}

Further, research has been undertaken in the mobile telecommunications sector to examine the link between service quality and customer satisfaction. From a Chinese mobile users' perspective, Lai et al. (2009) found no significant relationship between service quality and customer satisfaction. There is also extensive evidence in empirical literature that a positive and significant relationship does exist between service quality and customer satisfaction (Deng, 2010; Gao et al., 2015). Mpwanya (2019) investigated the overall level of customer satisfaction with service delivery of mobile network operators in South Africa making use of the Minnesota Customer Satisfaction Index and overall satisfaction measures. Mpwanya (2019) found that South African customers were highly satisfied with the service they were receiving from their mobile network operators. Mpwanya (2019) further reported that the ratio of customers dissatisfied with the service they were receiving from mobile network operators was also high and this had a negative influence on the reputation of mobile network operators. Another South African study by RobertsLombard and Petzer (2018) investigated "customer satisfaction/delight and behavioural intentions of cell phone network customers". The study reported that customer satisfaction/delight experiences were positively influenced by perceived employee service delivery skills.

Customer characteristics are critical to markers as they play an important role in market segmentation. Hence, it is therefore crucial to examine the boundaries at which SERVQUAL factors will predict or fail to predict customer satisfaction in South Africa's mobile telecommunications sector. Extant empirical evidence found that customer characteristics contributed significantly to satisfaction especially the aspect of sex that is biologically being a man or female (Bryant \& Jaesung, 1996; Mittal et al., 2001). Cooil et al. (2007) provided evidence to indicate that customer characteristics also influenced customer satisfaction outcomes among them, intention to repurchase, and wallet share. Research has argued for women being greatly satisfied (Buller \& Buller, 1987), while men are less satisfied (Chissick, 1997; Signh, 1990). Research further points to differential treatment of men and women by customer service staff leading to disparities in satisfaction levels between men and women (Iacobucci \& Ostrom, 1994; Weimann, 1988). On the contrary, Carmel (1985) and Linn (1982) provided evidence revealing that sex is unrelated to satisfaction. The study by Behe and Dennis (2009) provided evidence indicating that the customer's age is related to satisfaction. Further Díaz (2017) mentioned that several studies have been undertaken in the mobile telecommunications sector which revealed that customer characteristics, among them, income level, age and education level influenced customer satisfaction.

Given the above discussion, this study hypothesised that:

$\mathrm{H}_{1}$ : Tangibility, reliability, responsiveness, empathy, and assurance predicts customer satisfaction after controlling for sex, age and education level.

\section{METHODOLOGY}

The study is cross-sectional and quantitative in nature. A positivist paradigm was adopted. Thus, the study made use of numbers to test the hypothesis formulated based on theory. The hypothesis was formulated at the beginning of the study and remained unchanged until the end of the study. The hypothesis tested in this study stated that service quality as measured by tangibility, reliability, responsiveness, empathy and assurance predicts customer satisfaction experience in the South African mobile network telecommunications sector. 


\subsection{Research procedure}

Making use of convenience sampling, a non-probability sampling technique, data was gathered once, in a period of a month, and therefore this study is cross-sectional by design. Trained field workers, 156 in total, participated in the data collection process through a survey. Field workers distributed selfadministered questionnaires which contained closed-ended questions. Participants were informed of their rights to privacy, termination of participation at any time, confidentiality and that data collected was to be used for research and teaching purposes. Having outlined these rights to participants, their informed consent was sought and obtained. Data was collected from 1544 participants and after the data preparation process, 1451 questionnaires had sufficient data to proceed to the analysis stage. The Worldometer (2020) estimated that South Africa has a population of 59.6 million people with at least 101.9 million mobile network subscribers (organisations and individuals). Making use of the Raosoft sample size calculator, the recommended sample was derived as 385 . However, the researcher relied on a sample of 1451.

\subsection{Participants}

The dominant group was composed of people aged 25 and below, represented by $61 \%$. The second dominant group was made up of participants aged 26-30 represented by 25\%, followed by the 31-35 years category represented by $8 \%$. The 36-40 years category was represented by $4 \%$ while the $41-45$ years and the 46 years and above were both represented by $1 \%$ each. Fifty three percent of the participants were females and $47 \%$ represented male participants. The distribution of participants' education level revealed that $22 \%$ were matric certificate holders, $7 \%$ were diploma holders, $48 \%$ were first graduate degree holders, while postgraduate degree/diploma, master degree and $\mathrm{PhD}$ holders were represented by $13 \%$, $7 \%$ and 3\% respectively. The majority of the respondents were Xhosa speaking represented by $67 \%$, followed by isiZulu with $14 \%$, Sotho $7 \%$, English $4 \%$, Tswana 3\%, Afrikaans $2 \%$ and $3 \%$ for other languages.

\subsection{Measures}

To measure service quality, an approach was taken identical to that used by various authors who investigated service quality and customer satisfaction in the mobile network telecommunications sector across the globe. These studies adopted and to a certain degree modified the SERVQUAL scale (see, Agyapong, 2011, Loke et al., 2011, Selelo \& Lekobane, 2017). The modified SERVQUAL scale originally developed by Parasuraman et al. (1985) was used in this study. The SERVQUAL model reiterates that if an individual organisation is to achieve customer satisfaction, focus must be on delivering service in line with customer expectations. The SA mobile network market is unique and offers the customer two options of either calling the call centre or visiting the retail shop owned by the mobile network operator. As a result, tangibility, reliability, responsiveness, empathy and assurance were the SERVQUAL dimensions that were considered relevant to this study.

Tangibility was measured by four items with a reliability score of .774 , reliability was measured by five items with a reliability score of .802 , responsiveness was measured by four items with a reliability score of .764 , empathy was measured by five items with a reliability score of .805 , and assurance was measured by four items with a reliability score of .785. The SERVQUAL items were measured on a 7-point Likert scale anchored by $1=$ strongly disagree and $7=$ strongly agree being the highest score. The customer satisfaction scale was subdivided into two parts. The first part had four items with the reliability score of .858 . These four items were measured on a 7 -point Likert scale anchored by $1=$ very dissatisfied and $7=$ very 
satisfied as the top score. The second part of the customer satisfaction scale had 2 items with a reliability score of .821 . The two items were measured on a 7 -point Likert scale anchored by $1=$ very poor and $7=$ exceptional. The reliability scores of the scales utilised in this study were assessed through the Cronbach Alpha coefficient.

\subsection{Data analysis}

Data collected from a single source often suffers from common method bias and it must therefore be investigated and when found controlled so that the results are not contaminated or distorted by the bias. In this study, given that data was collected from a single source, Harman's (1976) single factor test was undertaken to detect whether the data suffered from common method bias issues. To perform this test, an exploratory factor analysis (EFA) was carried out where a fixed factor was extracted while a nonrotated solution was chosen. The resultant Harman's single factor test revealed that $39.121 \%$ of the variance was explained by a single factor and this figure is below the minimum threshold of $50 \%$. This outcome is an indicator that the data is free from common bias issues. Hierarchical regression analysis was undertaken to investigate whether tangibility, reliability, responsiveness, empathy and assurance would predict customer satisfaction after controlling for customers' sex, age and education level. The process of fitting a regression model was followed. Initial checks were carried out making use of scatterplots to investigate linearity and unusual cases between the predictor variables and the outcome variable. The resulting outcome scatterplots for customer satisfaction, given the three controlling variables and the five predictors, had reasonably linear relationships with the outcome variable, that is, customer satisfaction and there were no obvious outliers. Multicollinearity statistics were investigated focusing on the VIF values and the smallest was 1.004 and the largest value was 2.301. None of the VIF values were greater than 10 which according to Bowerman and O'Connell (1990) and Myers (1990) should be a cause for concern. However, Frost (2020) argues for VIF cut off equal to 5. Taking this into consideration, the study's results are still below the stated threshold. Further, the tolerance statistics were examined and the range was from .435 to .996 revealing that none of the tolerance statistics was below 0.2 which, according to Menard (1995), indicates a potential problem.

\section{RESULTS}

The study investigated whether service quality predicted customer satisfaction after controlling for the effects of age, sex and education level of customers. Hierarchical regression analysis was performed and the results shown in Table 1 (model summary section) revealed that age, sex and education level accounted for $.7 \%$ of the variability in customer satisfaction $(\mathrm{R} 2=.007)$. After the effects of age, sex and education level were accounted for, the predictors of customer satisfaction, that is service quality as measured by tangibility, reliability, responsiveness, empathy and assurance explained $52.3 \%$ of the variability in customer satisfaction $(\mathrm{R} 2$ change $=.523$ ). The results further reveal that the addition of the predictor variables (service quality) to the model yielded a statistically significant contribution towards the prediction of the outcome variable (customer satisfaction), given a significant F- change $=.000$. After controlling for the confounding variables, that is, sex, age and education level, the model was assessed for fitness and results revealed a statistically significant F-ratio equal to 207.785, $\mathrm{p}<.001$ (ANOVA section in Table 1). This outcome indicates that the model is significantly better at predicting customer satisfaction. Table 1, which is a combination of the ANOVA and Model summary output of the hierarchical regression analysis, provides a detailed description of the results. 
Table 1

Hierarchical regression model fit and summary output

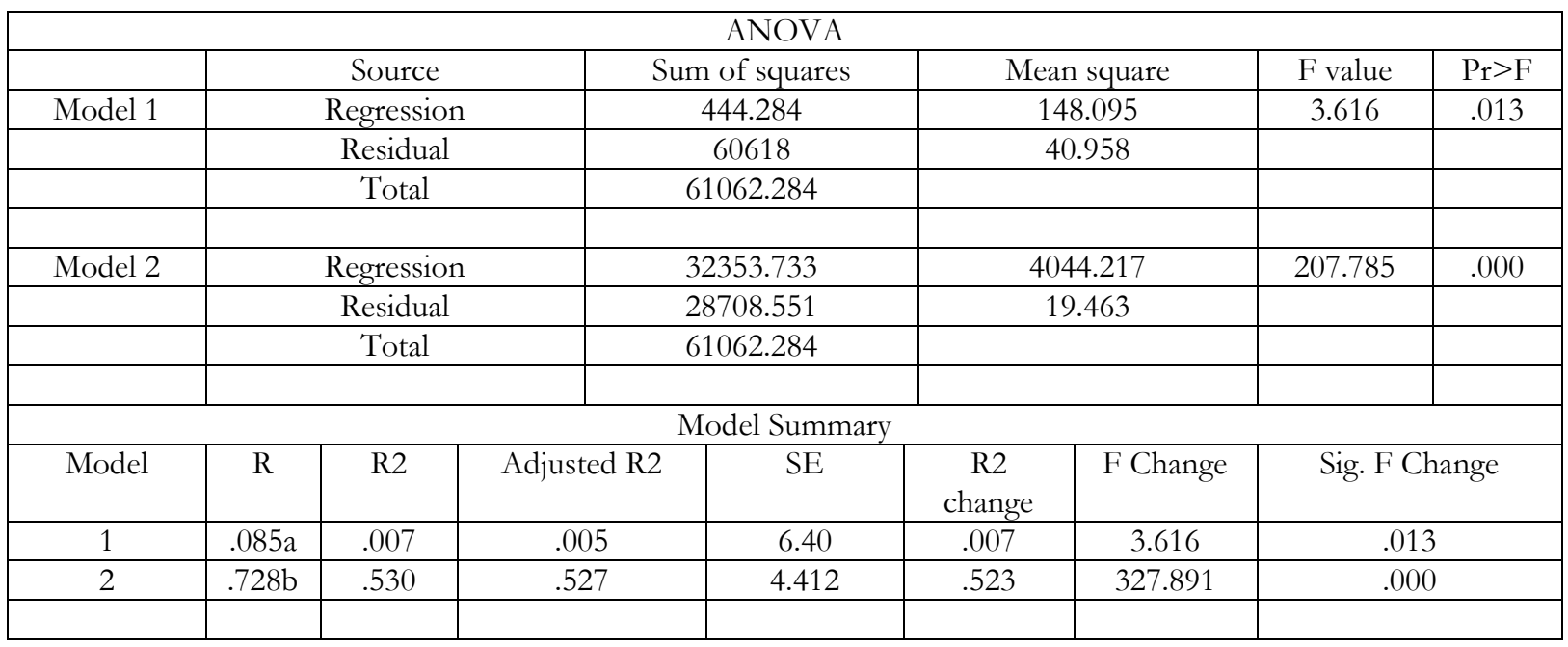

Source: Author's results. a. Predictors: (Constant), sex, age, education level. b. Predictors: (Constant), Sex, age, education level, tangibility, reliability, responsiveness, empathy, assurance. c. Dependent variable: customer satisfaction.

The parameter estimates from the resultant model were examined and observed. The results revealed that the respondent's sex had a unique and statistically significant negative contribution to the model, standard beta $=-.04, \mathrm{p}=.025$, while age (standard beta $=.029, \mathrm{p}=.128$ ), and education level (standard beta $=.003, \mathrm{p}=.888)$, had no unique contribution to the model respectively. The service quality dimensions were also examined and the results revealed that they all contributed uniquely to the model, tangibility (standard beta $=.187, \mathrm{p}<.001$ ), reliability (standard beta $=.161, \mathrm{p}<.001$ ), responsiveness (standard beta $=.09, \mathrm{p}<.001$ ), empathy (standard beta $=.151, \mathrm{p}<.001$ ), and assurance (standard beta $=.299, \mathrm{p}<.001)$. Since the SERVQUAL dimensions' coefficients were observed to be positive and significant, the study concluded that there is enough evidence at the $5 \%$ level of significance to support the thinking that after controlling for the effects of sex, age and education level, service quality as measured by SERVQUAL dimensions (tangibility, reliability, responsiveness, empathy and assurance) predict customer satisfaction in South Africa's mobile network telecommunications sector. Table 2 summarises the results discussed.

Table 2

Parameter estimates for the predictors of customer satisfaction

\begin{tabular}{|l|c|c|c|}
\hline & $\begin{array}{c}\text { Standardised Coefficients } \\
\text { Beta }\end{array}$ & Sig \\
\hline \multicolumn{1}{|c|}{ Model 1 } & & & \\
\hline Constant & - & 48.626 & .000 \\
\hline Sex & -.038 & -1.453 & .147 \\
\hline Age & .076 & 2.771 & .006 \\
\hline Education level & .007 & .262 & .793 \\
\hline$\quad$ Model 2 & & & \\
\hline Constant & - & 4.317 & .000 \\
\hline Sex & -.04 & -2.243 & .025 \\
\hline Age & .029 & 1.523 & .128 \\
\hline
\end{tabular}




\begin{tabular}{|l|c|c|c|}
\hline Education level & .003 & 141 & .888 \\
\hline Tangibility & .187 & 8.433 & .000 \\
\hline Reliability & .161 & 6.061 & .000 \\
\hline Responsiveness & .090 & 3.508 & .000 \\
\hline Empathy & .151 & 5.563 & .000 \\
\hline Assurance & .299 & 11.531 & .000 \\
\hline
\end{tabular}

Source: Author's results. Dependent variable: Customer satisfaction.

\section{DISCUSSION}

\subsection{Contributions to practice on customer satisfaction in the mobile network telecommunications sector}

Customer satisfaction experience in the mobile network telecommunications sector could be enhanced in South Africa if the players in the sector focus extensively on items that contribute significantly towards the satisfaction of customers. In this study, it was revealed that service quality accounts for $52.3 \%$ of the variability in customer satisfaction experience, $\mathrm{R} 2$ change $=.523$. This was after controlling for the effects of sex, age and education level of customers. Controlling for customer characteristics such as sex, age and education level is critical to South African mobile network operators who interested in segmenting their markets. This study as shown that customers' sex has a unique contribution towards customer satisfaction as opposed to other age and education level.

According to Mazibuko (2013), serious firms go out of their way in an attempt to keep their customers satisfied. This is because a satisfied customer is highly loyal to the firm and this normally translates to repeat purchase resulting in better business performance. Accordingly, competitive firms always want to keep their customers happy by promising what they know that they can deliver but then deliver more than what they had promised. Given that SERVQUAL dimensions explained $52.3 \%$ of the variability in customer satisfaction, mobile network operators can identify certain elements within SERVQUAL that they know very well they have no challenges in delivering and make promises to their customer, based on these but then deliver more than what they have promised. This should be done taking into consideration their sex. By so doing, customer satisfaction would be enhanced. Enhancing customer satisfaction is critical given that delighted customers further engage in the word-of-mouth practice that is telling other potential customers about their good experience with the mobile network operator. Word-of-mouth marketing is critical as it adds credibility to the mobile network operator (Barton, 2008). What this result further means is that there are other factors which firms cannot afford to ignore that account for $47.7 \%$ of the variation in customer satisfaction experience. In this study, the customer's sex is one of those factors that was found to have a unique negative contribution to customer satisfaction (standard beta $=-.04$ ), in contrast to existing empirical evidence which pointed out that satisfaction is unrelated to customer's sex (Carmel, 1985; Linn, 1982, Musekiwa et al., 2011). Thus, given the sensitivity of the subject, firms in the mobile network telecommunications sector should undertake extensive market research to identify and understand these factors. That could go a long way in an attempt to enhance overall customer satisfaction. This is critical as extant literature reveals that many firms lose up to $50 \%$ of their customers as they fail to meet customer expectations (Lamb et al., 2015).

\subsection{Contribution to promoting literature on service quality and customer satisfaction}

The SERVQUAL dimensions, that is, tangibility, reliability, responsiveness, empathy, and assurance accounted for $52.3 \%$ of the variation in customer satisfaction, $\mathrm{R} 2$ change $=.523$. The findings further 
revealed that a positive relationship exists between service tangibility and customer satisfaction, $\beta=.187$. This means that given an increase by one unit in service tangibility, customer satisfaction experience in the mobile network telecommunications sector would positively improve by 187 units. A positive relationship was also observed between service reliability and customer satisfaction, $\beta=.161$. This means that with an increase by one unit in service reliability, customer satisfaction experience in the mobile network telecommunications sector would improve by .161 units. Service responsiveness was also observed to positively relate with customer satisfaction, $\beta=.09$. This finding also means that as service responsiveness improves by one unit, there is a corresponding improvement in customer satisfaction experience in the mobile network telecommunications sector equivalent to .09 units. Empathy was found to positively relate with customer satisfaction, $\beta=.151$. Given this result, it can also be concluded that as empathy increases by one unit, there is a corresponding improvement in customer satisfaction experience in the mobile network telecommunications sector equivalent to .151 units. Service assurance was further found to have a positive relationship with customer satisfaction, $\beta=.299$. This finding means that as service assurance increases by one unit, there is a corresponding improvement in customer service experience in the mobile network telecommunications sector equivalent to .299 units.

\section{LIMITATIONS OF THE STUDY}

Primary data was gathered from a single province but South Africa has nine provinces. Although a large sample of 1451 was relied on in making conclusions, the reader must approach the study's results, interpretation and generalisations made with caution.

\section{FURTHER RESEARCH}

The majority of studies investigating service quality and customer satisfaction in the mobile network telecommunications sector have mostly taken the quantitative route, making use of structured questionnaires made up of closed-ended questions. Further, the majority of such studies are crosssectional by design. Research is needed to explore this complex issue from a qualitative or mixed-methods approach making use of longitudinal design given that the issue of service quality and customer satisfaction varies significantly with time.

\section{CONCLUSION}

The study investigated the influence of service quality as measured by tangibility, reliability, responsiveness, empathy and assurance on customer satisfaction after controlling for the effects of customers' sex, age and education level. Of the five dimensions of service quality, assurance had the highest beta value of .299 followed by tangibility at .187, indicating that these two dimensions play the most critical role in enhancing customer satisfaction experience in SA's mobile network telecommunications sector. Responsiveness had the lowest beta value of .09 indicating that among the five dimensions of SEVQUAL, responsiveness contributed very little towards customer satisfaction experience in the mobile network service industry in SA. Collectively, the five dimensions play a significant role in explaining customer satisfaction of SA customers in the mobile network telecommunications sector as they account for $52.3 \%$ of the variation in customer satisfaction experience. This study therefore concludes that service quality dimensions namely, tangibility, reliability, responsiveness, empathy and assurance are able to significantly predict customer satisfaction experience in 
SA's mobile network telecommunications industry after controlling for the effects of customers' sex, age and education level.

\section{ACKNOWLEDGEMENT}

No grants were received in carrying out this study. The author is grateful to fieldworkers. Their desire to practically experience research work at first hand contributed immensely to the success of the project.

\section{REFERENCES}

Agyapong, G.K. (2011). The Effect of Service Quality on Customer Satisfaction in the Utility Industry- A Case of Vodafone (Ghana). International Journal of Business and Management, 6(5), 203-210.

Alabar, T.T., Egena, O., \& Gbande, R.I. (2014). Service Quality and Customer Satisfaction in Nigerian Mobile Telephony. Proceedings of the 2014 3rd International Conference on Business, Management and Governance IPEDR vol.82, 108-118. IACSIT Press, Singapore.

Barton, S. (2008). Word-of-mouth marketing - Report back. Marketing Mix-Strategic Insights, 26(1/2).

Behe, B. K., \& Dennis, J. H. (2009, June). Age influences gardening purchases, participation, and customer satisfaction and regret. In XVI International Symposium on Horticultural Economics and Management 831 (pp. 179-184).

Berman, B. (2005). How to delight your customers. California Management Review, 48(1), 129-151.

Bowerman, B.L. \& O’Connell, R.T. (1990). Linear statistical models: An applied approach (2nd ed.). Belmont, CA: Duxbury.

BrandsEye. (2019). SA Telco Sentiment Index Consumers threaten to quit networks as half of all complaints go unanswered and Vodacom bungle implementation of Icasa data regulations. (28 April 2019). From: https:/ www.brandseye.com/research/sa-telco-sentiment-index-highlights-consumer-unhappiness/

Bryant, B.E., \& Jaesung, C. (1996). Crossing the threshold. Journal of Marketing Research, 8(4), 20-28.

Buller, M.K., \& Buller, D.B. (1987). Physicians communication style and patient satisfaction. Journal of Health and Social Behaviour, 28, 375-88.

Buttle, F., \& Maklan, S. (2015). Customer relationship management: Concepts and technologies (3rd edn). Routledge: New York.

Carmel, S. (1985). Satisfaction with hospitalization: A comparative analysis of three types of services. Social Science and Medicine, 21, 375-388.

Chisick, M. C. (1997). Satisfaction of active duty soldiers with family dental care. Military Medicine, 162(2), 105-108.

Cooil, B., Timothy, L.K., Lerzan, A., \& Micheal, H. (2007). A longitudinal analysis of customer satisfaction and share of wallet: Investigating the moderating effect of customer characteristics. Journal of Marketing, 71, 67-83.

Deng, Z., Lu, Y., Wei, K. K., \& Zhang, J. (2010). Understanding customer satisfaction and loyalty: An empirical study of mobile instant messages in China. International Journal of Information Management, 30(4), 289-300.

Díaz, G. R. (2017). The influence of satisfaction on customer retention in mobile phone market. Journal of Retailing and Consumer Services, 36, 75-85.

Frost, J. (2020). Multicollinearity in Regression Analysis: Problems, Detection, and Solutions. Retrieved from: https://statisticsbyjim.com/regression/multicollinearity-in-regressionanalysis/\#: :text=Multicollinearity $\% 20$ occurs $\% 20$ when $\% 20$ independent $\% 20$ variables, model $\% 20$ and $\% 20$ inte rpret $\% 20$ the $\% 20$ results.

Füller, J., \& Matzler, K. (2008). Customer delight and market segmentation: an application of the three-factor theory of customer satisfaction on life style groups. Tourism Management, 29(1), 116-126.

Gao, L., Waechter, K. A., \& Bai, X. (2015). Understanding consumers' continuance intention towards mobile purchase: A theoretical framework and empirical study - a case of China. Computers in Human Behaviour, 53, 249-262.

Harman, H.H. (1976). Modern factor analysis (3rd ed. Revised). Chicago, IL.: University of Chicago Press, NY: Continuum International Publishing group. 
Hudson, S., \& Hudson, L. (2017). Marketing for tourism, hospitality \& events: a global \& digital approach. Thousand Oaks: Sage.

Iacobucci, D., \& Ostrom, A. (1993). Gender differences in the impact of core and relational aspects of services on the evaluation of service encounters. Journal of Consumer Psychology, 2(3), 257-286.

ICASA. (2019). State of ICT Sector in SA - 2019 report. Retrieved from: https://www.icasa.org.za/legislation-andregulations/state-of-ict-sector-in-south-africa-2019-report

Izogo, E.E. (2016). Should relationship quality be measured as a disaggregated or a composite construct? Management Research Review, 39(1), 115-131.

Izogo, E.E. (2017). Customer loyalty in telecom service sector: the role of service quality and customer commitment. The Total Quality Management Journal, 29(1), 19-36.

Lai, F., Griffin, M., \& Babin, B. J. (2009). How quality, value, image, and satisfaction create loyalty at a Chinese telecom. Journal of Business Research, 62(10), 980-986.

Lamb, C.W., Hair, J.H., McDaniel, C., Boshoff, C., Terblanche, N., Elliot, R., \& Klopper, H.B. (2015). Marketing (5th edn). Oxford University Press, Southern Africa: Cape Town.

Linn, L.S. (1982). Burn patients' evaluation of emergency department care. Annals of Emergency Medicine, 11, 255-259.

Loke, S., Taiwo, A.A., Salim, H.M. \& Downe, A.G. (2011). Service quality and customer satisfaction in a telecommunication service provider. In International Conference on Financial Management and Economics, 11(2), 23-29.

Machado, R. (ed.). (2014). Customer Service (2nd edn). Juta: Cape Town.

Martinelli, E., \& Balboni, B. (2012). Retail service quality as a key activator of grocery store loyalty. The Service Industries Journal, 32(14), 2233-2247.

Mazibuko, N.E. (2013). Marketing: Creating and capturing customer value. In Kotler, P. \& Armstrong, G. (eds). Principles of Marketing: Global and Southern African Perspectives (2nd edn). pp. 2-33. Cape Town: Pearson.

Menard, S. (1995). Applied logistic regression analysis. Sage University Paper Series on Quantitative Applications in the Social Sciences, 07-106. Thousand Oaks, CA: Sage.

Mittal , V., Wagner, A., \& Kamakura, W.A. (2001). Satisfaction repurchase intent and repurchase behaviour: Investigating the moderating effect of customer characteristics. Journal of Marketing Research, 38, 131-142.

Mpwanya, M.F. (2019). An Empirical Examination of the Overall Customer Satisfaction with the Service Delivery of Mobile Network Operators in South Africa. Global Business Review, 1-17.

Musekiwa, A., Njanike, K., \& Mukucha, P. (2011). Gender effects on customer satisfaction in banking industry: a case of commercial banks in Bindura, Zimbabwe. Journal of Business Management and Economics, 2(1), 040-044.

Myers, R. (1990).Classical and modern regression with applications (2nd ed.) Boston, MA: Duxbury.

Ngwenya, M. (2017, December). Analysing service quality using customer expectations and perceptions in the South African telecommunication industry. In 2017 IEEE International Conference on Industrial Engineering and Engineering Management (IEEM) (pp. 1094-1097). IEEE.

Olatukun, W.M., \& Ojo, F.O. (2016). Influence of service quality on consumers' satisfaction with mobile telecommunication services in Nigeria. Information Development, 32(3), 398-408.

Parasuraman, A., Zeithaml, V.A. \& Berry, L.L. (1985).A Conceptual Model of Service Quality and its Implication. Journal of Marketing, 49, 41-50.

Parasuraman, A., Zeithaml, V.A., \& Berry, L.L. (1988). A multiple-item scale for measuring consumer perceptions of service quality. Journal of Retailing, 64(1), 12-40.

Roberts-Lombard, M., \& Petzer, D.J. (2018). Customer satisfaction/delight and behavioural intentions of cell phone network customers - an emerging market perspective. European Business Review, 30(4), 427-445.

Selelo, G.B., \& Lekobane, K.R. (2017). Effects of Service Quality on Customers Satisfaction on Botswana's Mobile Telecommunications Industry. Archives of Business Research, 5(3), 212-228.

Singh, J. (1990). A multifacet typology of patient satisfaction with a hospital. Journal of Health Care Marketing, 10(4), 821.

Torres, E.N., \& Kline, S. (2013). From customer satisfaction to customer delight: creating a new standard of service for the hotel industry. International Journal of Contemporary Hospitality Management, 25(5), 642-659. 
Van der Wal, R. W. E., Pampallis, A., \& Bond, C. (2002). Service quality in a cellular telecommunications company: A South African experience. Managing Service Quality: An International Journal, 12(5), 323-335.

Weimann, G. (1985). Sex differences in dealing with bureaucracy. Sex Roles, 12(7/8), 777-790.

Worldometer. (2020). South African population. Available: https://www.worldometers.info/worldpopulation/south-africa-population/

Zeithaml, V.A., Bitner, M.J., \& Gremler, D.D. (2013). Services Marketing: integrating customer focus across the firm (6th edn). McGraw-Hill Irwin: New York. 